\title{
WACANA RANCANGAN MATERI EKONOMI ISLAM DALAM MATA PELAJARAN ILMU PENGETAHUAN SOSIAL DI MADRASAH IBTIDA'IYAH
}

\author{
M. Musyafa \\ Sekolah Tinggi Agama Islam (STAIN) Al-Falah Jayapura, Papua \\ Email: mmusyafa@gmail.com
}

\begin{abstract}
Islamic values should be built in educational institution as early as possible, at least from elementary school. It might be rather difficult to think of Islamic values being taught in the elementary school, especially in social studies subject. One idea was by focusing students learning process on the development of certain values, such as, wealthiness, fairness, honesty, responsibility, and prohibition of practicing usury. Educating the students with those values were believed to contribute to the development of Islamic values in later age. This paper provides some ideas within which the mentioned values were taught in elementary school.
\end{abstract}

Keywords: Islamic economics, education, Elementary School

\begin{abstract}
Abstrak: Kepribadian Islam harus ditanamkan sedini mungkin melalui pendidikan, yaitu sejak pendidikan dasar. Pembentukan karakter anak sejak berada di sekolah dasar, akan memberikan pengaruh yang lebih besar bagi mereka ketika mereka tumbuh dewasa, seperti pepatah yang mengatakan belajar di waktu kecil seperti mengukir di atas batu dan belajar di usia tua seperti mengukir di atas air. Belajar di tingkat SD harus difokuskan pada pembentukan karakter mereka, sehingga bahan-bahan ekonomi Islam yang tepat adalah seperti kesejahteraan, keadilan, pelarangan praktik riba, harus jujur dengan lingkungan sosial dan sebagainya.
\end{abstract}

Kata kunci: ekonomi Islam, pendidikan, Sekolah Dasar

\section{Pendahuluan}

Pada dasarnya ilmu ekonomi Islam memandang bahwa permasalahan ekonomi dapat dikelompokkan ke dalam dua hal, yaitu ilmu ekonomi (science of economic) dan doktrin ilmu ekonomi (doctrine of economics). Perbedaan ini terletak paradigma filosofinya, ekonomi memberikan ruh pemikiran dengan nilai-nilai islami dan batasan-batasan syari'ah, sedangkan ilmu ekonomi berisi alat-alat analisis yang dapat digunakan. Menurut Muhammad Baqir as-Sadr dalam Adiwarman, ekonomi Islam adalah sebuah ajaran atau doktrin yang tidak hanya merupakan ilmu pengetahuan saja, karena di dalamnya termuat hal-hal yang memberikan sebuah solusi hidup yang baik, sedangkan ilmu ekonomi hanya akan mengantarkan siapa pun yang mempelajarinya kepada pemahaman bagaimana kegiatan ekonomi itu berjalan dan dijalankan. ${ }^{1}$ Kegiatan ekonomi dijalankan dalam rangka melakukan pembangunan dalam segala bidang ke arah yang lebih baik dan lebih maju, termasuk juga ketika bicara ekonomi Islam, menurut Setiawan sebagaimana yang dikutip oleh Nurman Hakim, konsep pembangunan dalam Islam memiliki sifat-sifat yang komprehensif dan mengandung nilai-nilai spiritual, moral dan materi, dalam konsep ini fokus pembangunannya adalah pribadi manusia itu sendiri. ${ }^{2} \mathrm{Hal}$ ini bisa dilakukan sedini mungkin agar hasilnya lebih maksimal, sebagaimana ketika seseorang membangun sebuah rumah, maka ketika dia

\footnotetext{
${ }^{1}$ Adiwarman A. Karim, Ekonomi Mikro Islami, (Jakarta: PT. Raja Grafindo Persada, 2008), h. 4.

${ }^{2}$ Nurman Hakim, "Visi, Misi dan Nilai Perusahaan dalam pemasaran perbankan Syari'ah”, dalam Jurnal Review of Islamic Economics, Finance, and Banking 1(1), 2013, h. 141.
} 
hanya membaguskan dan memperkuat atapnya saja tanpa menghiraukan bagaimana kekuatan dari pondasi dan tiang-tiangnya, maka usahanya ini tidaklah berguna baginya. Pembangunan ekonomi merupakan aktivitas yang multidimensional, karena di dalamnya akan menimbulkan sejumlah perubahan secara kuantitatif maupun kualitatif. Bahkan dengan adanya prinsip sosial Islam yang dinamis untuk pemanfaatan sumber daya alam dengan semangat keadilan bagi seluruh umat manusia ${ }^{3}$.

Ekonomi sebagai sebuah ilmu pengetahuan merupakan segala teori atau hukum-hukum dasar yang menjelaskan perilaku-perilaku antarvariabel ekonomi tanpa memasukkan unsur norma ataupun aturan-aturan tertentu, sedangkan secara filosofis ekonomi adalah ilmu ekonomi murni yang memasukkan norma-norma dan tata aturan tertentu sebagai variabel yang secara langsung atau tidak langsung ikut mempengaruhi fenomena ekonomi. Dalam ekonomi Islam norma dan tata aturan tertentu tersebut berasal dari Allah Swt, yang meliputi batasan-batasan dalam melakukan kegiatan ekonomi.

Dalam proses integrasi antara ekonomi secara filosofis ke dalam ilmu ekonomi secara murni disebabkan adanya pandangan bahwa kehidupan di dunia tidak dapat dipisahkan dengan kehidupan akhirat, semuanya haruslah seimbang karena dunia adalah ladang untuk menggapai akhirat yang lebih baik, sebagaimana sabda Nabi Saw. "al-addunya mazra'at alâkhirah". ${ }^{4}$

Hal juga sejalan dengan firman dalam surat al-Zalzalah sebagai berikut :

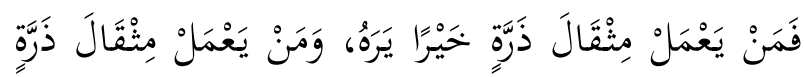

$$
\text { شَرَّا يَرَهُ . }
$$

Artinya: "Barangsiapa yang mengerjakan kebaikan seberat dzarrahpun, niscaya Dia akan

\footnotetext{
${ }^{3}$ Nurman Hakim, "Visi, Misi dan Nilai Perusahaan dalam pemasaran perbankan Syari'ah”, h. 141.

${ }^{4}$ Nurman Hakim, "Visi, Misi dan Nilai Perusahaan dalam pemasaran perbankan Syari'ah”, h. 5 .
}

melihat (balasan)nya, dan barangsiapa yang mengerjakan kejahatan sebesar dzarrahpun, niscaya Dia akan melihat (balasan)nya pula". (QS. al-Zalzalah/99 : 7-8).

Ayat tersebut menjelaskan tentang betapa pentingnya memperhatikan kepentingan dua hal yakni kepentingan duniawi dan kepentingan ukhrawi, yakni ketika seseorang tidak boleh menggunakan semua waktunya dalam kehidupan ini difokuskan untuk menggapai dunia saja, dengan berpedoman pada prinsip bahwa hal-hal yang menguntungkan secara duniawi berarti dialah yang benar dan harus dikejar, sedangkan yang merugikan secara duniawi berarti dia harus dihindari. Akan tetapi, harus berpedoman pada prinsip-prinsip kebaikan dalam arti yang lebih luas yaitu yang bersifat ukhrawi, karena setiap kebaikan apapun apakah itu dipandang kecil oleh sebagian orang ataukah yang sifatnya besar tidak boleh dihiraukan, dan sebaliknya ketika hal itu sebuah kejelekan baik itu kecil ataupun besar juga tidak boleh diremehkan, karena setiap manusia akan mendapatkan balasannya.

Dengan demikian, hadirnya pendidikan tingkat dasar menjadi suatu keharusan bagi setiap muslim untuk melakukan pembelajaran guna membangun karakter pribadi-pribadi muslim yang handal, manusia yang baik sesuai dengan yang diperintahkan oleh Allah Swt., dan pada Sekolah Dasar atau Madrasah Ibtidaiyah inilah merupakan jenjang pendidikan yang harus dilalui oleh semua anak-anak. Pada fase inilah karakter anak dibentuk secara mendasar, sehingga penting sekali untuk senantiasa diperhatikan. Pembentukan karakter seperti apa yang diinginkan oleh pendidik, tidak terlepas dari nilai-nilai yang positif. Setiap insan yang hidup di dunia ini orientasinya adalah antara profit atau non-profit, duniawi atau ukhrawi, dan finansial atau sosial. 
Pentingnya Pendidikan Ekonomi Islam untuk Sekolah Dasar

Pribadi yang Islami haruslah dibentuk sedini mungkin melalui pendidikannya, yakni sejak di Pendidikan Dasar. Pembentukan karakter semenjak anak-anak di bangku Sekolah Dasar akan memberi pengaruh yang lebih besar kepada mereka ketika mereka beranjak dewasa nanti, sebagaimana sebuah pepatah mengatakan belajar di waktu kecil bagai mengukir di atas batu dan belajar di waktu besar bagai mengukir di atas air. Ini artinya pembelajaran ketika di tingkat dasar memang agak sulit dan memerlukan waktu yang agak lama dibandingkan dengan pembelajaran ketika beranjak remaja bahkan dewasa, yang mana biasa akan lebih mudah untuk memahami sesuatu namun terkadang akan mudah untuk dilupakan, karena tertimpa dengan pengetahuanpengetahuan lainnya. Pembelajaran bagi anakanak ini juga disinggung dalam al-Qur'an oleh Allah melalui sebuah kisah yang penuh hikmah, yaitu kisah tentang pengajaran yang dilakukan oleh Luqman yang merupakan salah satu hamba Allah yang sangat shalih, sebagaimana dalam ayat berikut :

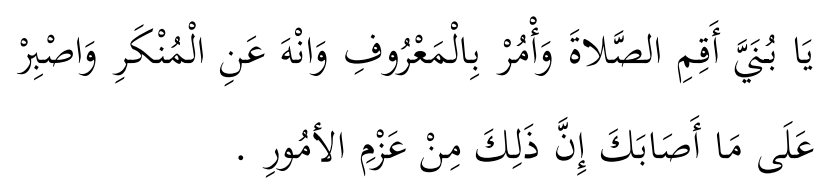

Artinya : "Hai anakku, dirikanlah shalat dan suruhlah (manusia) mengerjakan yang baik dan cegahlah (mereka) dari perbuatan yang mungkar dan bersabarlah terhadap apa yang menimpa kamu. Sesungguhnya yang demikian itu termasuk hal-hal yang diwajibkan (oleh Allah)". (Lukman/ 31: 17).

Dari ayat tersebut, dapat diambil penjelasan bahwa memberikan pendidikan dan pembelajaran pada anak-anak akan memberikan kemanfaatan yang sangat besar, seperti yang lakukan Luqman kepada anaknya, dia menasehatinya agar dia senantiasa mendirikan shalat secara konsisten dengan kesadaran penuh dan memerintahkan yang baik-baik kepada orang lain, dengan sudah pasti tidak melupakan diri sendiri ketika meminta orang lain untuk melakukan kebaikan, dan bukan hanya memerintahkan berbuat kebaikan, tetapi juga melarang untuk berbuat hal-hal yang munkar, yakni hal-hal yang tidak sesuai dengan aturanaturan yang ada, aturan-aturan yang telah disepakati bersama, aturan-aturan yang telah dibuat oleh Allah Swt, untuk kelangsungan hidup manusia.

Hal ini mengingat pendidikan merupakan suatu proses dalam rangka mempengaruhi siswa agar dapat menyesuaikan diri sebaik mungkin terhadap lingkungannya, dengan demikian dapat menimbulkan perubahan dalam dirinya dan dapat berfungsi secara baik dalam kehidupan masyarakat. Sedangkan pengajaran mengarahkan proses pendidikan ini agar sasaran perubahan itu dapat tercapai sebagaimana yang diinginkan. ${ }^{5}$

Nilai-nilai yang terkandung dalam ekonomi Islam merupakan nilai-nilai yang bersifat universal dan mendasar, sehingga sangat sesuai untuk mata pelajaran di tingkat dasar yang berfokus pada pembentukan mental anak untuk bekalnya di masa mendatang yang tantangannya lebih berat tentunya dengan masa-masa kita sekarang, sebagaimana Rasulullah saw. dalam salah satu riwayat bersabda "Ajarilah anakanakmu sesuai dengan perkembangan zamannya!”.

Seiring dengan perkembangan ilmu-ilmu sosial, ilmu ekonomi juga mengalami perkembangan yang pesat, sehingga wacana untuk memasukkan kurikulum ekonomi Islam pada mata pelajaran IPS atau mata pelajaran sosial lainnya di Sekolah Dasar merupakan

\footnotetext{
${ }^{5}$ Oemar hamalik, Proses Belajar Mengajar, (Jakarta: PT. Bumi Aksara, 2003), h. 79.
} 
sebuah keniscayaan yang harus segera dicanangkan oleh pemerintah dan juga para pendidik di jenjang pendidikan dasar. Bahkan hal ini rupanya sejalan dengan visinya Presiden Indonesia Joko Widodo yang seringkali dalam pidato dan orasinya seringkali menyebutkan istilah revolusi mental. Revolusi mental ini akan lebih mudah dilakukan ketika generasi muda bangsa ini masih di level jenjang pendidikan dasar, agar memiliki karakter dasar yang lebih baik untuk menyongsong masa depannya kelak.

Pendidikan karakter ini, meskipun sudah masuk pada materi-materi pelajaran Pendidikan Agama Islam (PAI). Akan tetapi, materi yang telah ada dirasakan masih kurang menyeluruh, yakni hanya menyinggung tentang zakat dan tolong-menolong. Sebagaimana yang ada pada kurikulum Pendidikan Agama Islam untuk sekolah dasar berikut: pertama, pengenalan materi tentang surat-surat dan ayat-ayat dalam Al-Qur'an, yaitu surat al-Fâtihah yang merupakan ummul Qur'an dan pembukaan alQur'an, surat al-Kautsar yang merupakan surat paling pendek dalam al-Qur'an, surat al-Lahab, al-Kâfirûn yang merupakan penegasan tentang tauhid setelah surat al-Ikhlas, surat al-Qadar, surat al-'Alaq ayat 1-5 yang merupakan ayat pertama kali turun dan perintah membaca, surat al-Maidah ayat 3 yang merupakan ayat terakhir diturunkan pada Nabi Muhammad, surat alHujurat ayat 13 tentang penciptaan manusia yang berbeda-beda dan bersuku-suku agar saling mengenal.

Kedua, pengenalan tentang sifat jaiz bagi Allah, malaikat-malaikat Allah, Kitab-kitab Allah, Nabi dan Rasul, Rasul Ulul Azmi. Ketiga, pengenalan tentang hari akhir, Qadla dan Qadar, keempat kisah para sahabat termasuk khulafaurrasyidin, yakni Abu Bakar As-Shiddiq, Umar ibn Khattab, Utsman ibn Affan dan Ali ibn Abi Thalib. Kelima kisah tentang orangorang kafir Quraisy, yakni Abu Lahab, Abu Jahal, Musailamah Al-Kadzab. Keenam, kisah tentang kaum muhajirin dan kaum anshar. Ketujuh, menghindari perilaku dengki seperti
Abu Lahab dan bohong seperti Musailamah. Kedelapan, puasa, yakni rukun puasa, yang membatalkan puasa, dan hikmah puasa, ibadahibadah pada bulan Ramadhan. Kesembilan, zakat. Kesepuluh, shalat, yakni syarat dan rukun shalat, sunnah-sunnah dalam shalat, serta macam-macam shalat sunnah. ${ }^{6}$

Beberapa materi PAI untuk Sekolah Dasar tersebut menunjukkan belum terakomodasinya kajian-kajian mendasar terkait dengan ekonomi Islam. Padahal, materi-materi tersebut tidak bisa dibilang tidak lebih penting dari pada materimateri yang sudah ada tersebut. Materi-materi ekonomi Islam ini cukup sulit jika harus dimasukkan menjadi bagian dari materi-materi PAI. Hal tersebut berdasarkan pertimbangan karena mengingat terlalu banyaknya materi PAI, sehingga pengajarannya terhadap peserta didik akan menjadi tidak bisa maksimal. Untuk itu, mengingat ekonomi Islam merupakan bagian dari ilmu sosial akan lebih berkembang jika masuk dalam materi pendidikan sosial dengan penanaman karakter keislaman yang lebih mendalam. Hal ini akan menjadi pembeda generasi dengan pendidikan keislaman dengan pendidikan konvensional.

\section{Materi-materi Mata Pelajaran Ekonomi Islam untuk Sekolah Dasar}

Menurut Adam Smith, seorang pakar ekonomi klasik, ilmu ekonomi adalah ilmu kekayaan atau ilmu yang khusus mempelajari tentang sarana-sarana kekayaan suatu bangsa dengan memusatkan perhatian secara khusus terhadap sebab material dari kemakmuran. Sedangkan menurut Marshall dalam Ahmad Muhamad al-Asal, bahwa ilmu ekonomi adalah ilmu yang mempelajari usaha-usaha individu dalam ikatan pekerjaan di kehidupannya seharihari, ${ }^{7}$ sehingga setiap orang pasti akan

\footnotetext{
${ }^{6}$ Kurikulum PAI Sekolah Dasar,

7 Ahmad Muhammad Al-Asal dan Fathi Ahmad Abdul Karim, Sistem, Prinsip, dan Tujuan Ekonomi Islam, terj: Imam Saefudin, (Bandung: CV. Pustaka Setia, 1999), h. 10
} 
menjalankan aktivitas ekonomi dengan secara sadar atau tidak sadar, bersamaan dengan hal tersebut seharusnya dia mempelajarinya baik secara menyeluruh atau sebagaiannya saja.

Ilmu ekonomi Islam sudah merupakan keniscayaan yang harus dipelajari oleh setiap orang terutama oleh umat Islam, karena dengan mengamalkan ekonomi Islamlah umat Islam bisa sejahtera baik secara lahir maupun batin, sehingga perlu diperkenalkan kepada seseorang sejak mereka masih anak-anak agar mereka memahami dan mengerti serta mengaplikasikan nilai-nilai dan prinsip yang terdapat dalam ekonomi Islam.

Memformulasikan materi-materi dalam mata pelajaran ekonomi Islam untuk para siswa yang ada di sekolah dasar harus difokuskan pada hal-hal yang bersifat prinsip dan mendasar, dan bukan pada hal-hal yang bersifat analisis. Sebab masa-masa mereka inilah, kebutuhan akan pembentukan jiwa yang berkarakter baik, pribadi yang unggul bisa dilakukan sesuai dengan kemampuan anak yang senantiasa tanggap dan menerima sesuatu bersifat all out atau menyeluruh dan terfokus. Jika diperhatikan perilaku anak-anak, maka didapati bahwa mereka ketika menyukai tentang sesuatu maka jiwa raganya akan dipusatkan untuk itu dan cenderung tidak menghiraukan yang lain, bahkan ketika ada yang mengganggu kesenangannya atau konsentrasinya mereka akan berontak.

\section{Kesejahteraan}

Tujuan adanya ekonomi Islam adalah untuk kesejahteraan umat manusia baik di dunia maupun di akhirat. Istilah kesejahteraan ini dalam bahasa Arab terutama al-Qur'an seringkali menggunakan kata falâh, yang mana kata ini memiliki beberapa arti jika ditelusuri dari akar katanya, yakni berkembang pesat, menjadi bahagia, memperoleh keberuntungan, memperoleh kesuksesan, menjadi sukses. Dalam al-Qur'an kata falâh terdapat dalam 40 tempat. Falâh menyangkut konsep yang bersifat dunia dan akhirat. Adapun yang bersifat duniawi mencakup tiga pengertian, yaitu pertama kelangsungan hidup, kedua terbebas dari kemiskinan, dan ketiga kekuatan dan kehormatan. Sedangkan yang terkait dengan kesejahteraan akhirat mencakup pengertian terkait tiga hal juga, yaitu pertama kelangsungan hidup yang abadi, kedua kesejahteraan yang abadi, dan ketiga pengetahuan yang bebas dari segala kebodohan. ${ }^{8}$

Kelangsungan hidup dalam kesejahteraan di dunia dimaksudkan adalah ketika seseorang sudah mendapatkan kecukupan yang memadai untuk memenuhi kebutuhan dasarnya, yang meliputi sandang pangan dan papan secara minimal, sehingga dia bisa melanjutkan keberlangsungan hidupnya. Sedangkan untuk terbebas dari kemiskinan artinya bagi pribadi yang sejahtera, maka indikator-indikator kemiskinan yang ada padanya sudah tidak ada, misalkan seseorang dikatakan miskin, apabila dia tidak bisa mencukupi kebutuhannya dalam satu bulan atau setiap harinya secara layak atau dengan kata lain setiap penghasilannya tidak bisa menutupi kebutuhan pribadi dan keluarganya.

Oleh karena itu, ketika seseorang dikatakan terbebas dari kemiskinan maka hal ini tidaklah terjadi padanya, bahkan sebaliknya dia menjadi orang yang kaya dan mampu untuk memenuhi setiap kebutuhan diri dan keluarganya. Kekuatan dan kehormatan juga menjadi indikator seseorang telah sejahtera dalam kehidupan dunianya, yakni dia bisa menjalani kehidupan ini sebagai orang yang terhormat dengan akhlak yang mulia, seperti tidak meminta-minta, dan senantiasa suka memberi atau dermawan, sebagaimana misi Rasulullah SAW adalah

\footnotetext{
8 Hendrie Anto, Pengantar Ekonomika Mikro Islami, (Yogyakarta: Ekonesia, 2003), h. 7.
} 
membentuk akhlak yang mulia. Nabi Muhammad SAW bersabda, "sesungguhnya aku diutus hanya untuk menyempurnakan akhlak sehingga menjadi akhlak yang mulia”.

Muslim yang kuat lebih disukai oleh Allah SWT daripada muslim yang lemah, artinya seseorang dengan fisik yang kuat lebih mampu untuk berbuat baik lebih banyak daripada yang fisiknya lemah. Fisik yang kuat dapat diperoleh dengan asupan makan dan gizi yang cukup untuk menunjang semuanya, dengan syarat semua rezeki yang diperoleh dengan cara yang halal, sehingga ketika masuk ke tubuh melalui makanan akan menjadikan hati dan pikiran jernih sehingga karakter kepribadiannya juga mulia. Selain secara fisik kekuatan juga berarti mental yang kuat, tidak memiliki mental yang lemah, yang ketika ada sedikit godaan atau tekanan dari pihak-pihak yang akan berbuat tidak baik, dia bisa mengatasinya dengan baik.

Kesejahteraan akhirat juga menjadi tujuan penerapan ekonomi Islam, yaitu kelangsungan hidup abadi. Dalam kepercayaan umat Islam kehidupan dunia tidaklah bersifat abadi atau hanya sementara, sebagaimana ketika bayi di dalam kandungan seorang ibu, maka dia tidak selamanya berada di dalam. Setelah bayi itu lahir ke dunia, maka dia akan melanjutkan kehidupannya di dunia untuk mempersiapkan kehidupannya kelak di akhirat.

Kehidupan yang abadi setelah menginggalkan dunia ini haruslah dipersiapkan oleh kita semua dengan sebaik-baiknya, karena ketika hidup di dunia ini hanya digunakan untuk hal-hal yang bersifat duniawi, maka kelak di akhirat tidak akan mendapatkan apa-apa, dan menjadi orang yang rugi, sehingga tempatnya adalah neraka yang merupakan seburuk-buruk tempat kembali.

Tujuan kedua adalah kesejahteraan yang abadi, artinya ketika kita menggapai kesejahteraan duniawi dengan memperhatikan kesejahteraan akhirat, maka kedua kesejahteraan tersebut akan kita peroleh, sebagaimana sabda Nabi Saw, "setiap orang akan mendapatkan sesuai dengan yang diniatkannya”. Kesejahteraan abadi adalah surga yang merupakan sebaikbaiknya tempat kembali, yang telah disiapkan oleh Allah untuk setiap hamba-Nya yang senantiasa memfokuskan diri untuk menggapai ridha-Nya ketika masih hidup di dunia.

Di dalam al-Qur'an dijelaskan dengan berbagai macam kenikmatan dan kenyamanan yang sempurna, seperti setiap orang yang ada di surga disediakan tempat tidur yang bertahtakan emas dan permata sebagaimana firman Allah:

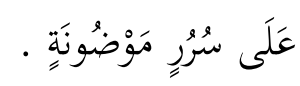

Artinya: "Mereka berada di atas dipan yang bertahta emas dan permata" (QS. Al-Waqiah / $56: 15)$.

Selain itu dalamnya dikelilingi oleh pemudapemuda yang tidak akan pernah tua sampai kapanpun, sehingga bagi para wanita tidak ada alasan untuk tidak betah di dalamnya (QS. alWaqi'ah 156 : 17), ketika di surga itu mereka minum dengan gelas dan teko dari air mengalir yang tidak akan membuat kepala sakit dan tidak pula membuat sesorang menjadi mabuk karenanya (QS. al-Waqiah /56: 18 dan 19), buah-buahan juga menjadi salah satu makanan yang bisa dinikmati oleh penghuni surga sesuka hatinya mau memilih yang mana saja dan buah apa saja yang diinginkan sudah disediakan oleh Allah (QS.Al-Waqi'ah /56 : 20).

Bagi orang yang suka daging burung, maka di dalamnya sudah disediakan oleh yang Maha bijaksana (QS. al-Waqi'ah 156 : 21), ada banyak bidadari yang bermata jeli sehingga enak dipandang dan membuat seseorang tidak ingin untuk berpindah tempat dan berlama-lama di dalamnya sebagiaman sudah disediakan oleh Allah untuk penghuni surga (QS. al-Waqi'ah $/ 56$ : 22) dan masih banyak lagi sifat-sifat surga yang merupakan bentuk pencapaian kesejahteraan sejati yang telah disediakan oleh Allah untuk setiap individu yang menginginkannya.

Ketiga adalah pengetahuan yang terbebas dari kebodohan, yakni pengetahuan tentang 
akhirat yang tidak pernah menipu, pengetahuan sejati, pengetahuan yang bukan seperti pengetahuan fatamorgana, yang di dalamnya penuh dengan tipu muslihat, pengetahuan yang bersifat sementara dan tidak kekal. Pengetahuan ini adalah pengetahuan yang berkaitan dengan bagaimana mencari keridhaan Allah dengan senantiasa istiqomah dan konsisten menjalankan perintah sesuai dengan yang diperintahkan oleh Allah, dan menjauhi atau menghindarkan diri dari apa yang dilarang atau tidak disukai oleh Allah SWT. Pengetahuan tentang yang baik dan yang buruk, pengetahuan tentang hukumhukum Allah yang halal dan yang haram, yang sunnah dan yang makruh, yang mubah dan yang syubhat. Semuanya harus diketahui dan dijalankan sesuai dengan yang dikehendaki oleh Allah yang membuat aturan.

Misalnya pengetahuan tentang baik dan buruk, bagaimana tata cara memperlakukan orang tua, memperlakukan tetangga, memperlakukan orang yang lebih muda atau lebih rendah derajatnya baik dari segi strata sosial maupun dari segi ekonominya. Pengetahuan tentang hukum-hukum, seperti bagaimanakah mencari penghidupan atau pekerjaan yang tidak dilarang oleh Allah?; Bagaimanakah berdagang yang diridhai Allah?; Bagaimanakah etika melakukan konsumsi yang diridhai Allah dan lain sebagainya?.

\section{Keadilan}

Allah adalah pencipta segala sesuatu, dan menjadi salah satu sifatnya adalah adil, sebagaimana yang ada dalam al-asma al-husna yaitu al-'adlu. Dia tidak membeda-bedakan perlakuan terhadap makhluk-Nya secara dzalim. Setiap manusia di muka bumi ini adalah khalifah Allah, sehingga dia harus memelihara hukumhukum Allah di bumi ini, dan menjamin bahwa pemakaian segala sumber daya yang ada di dalamnya diarahkan untuk kesejahteraan manusia, agar supaya semuanya dapat merasakan manfaatnya secara adil dan baik.

Banyak ayat-ayat yang memerintahkan untuk berbuat adil, diantaranya adalah QS. alMa’idah/5: 42, QS. al-Mumtahanah/60: 8, QS.

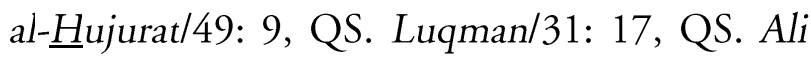
Imran/3:104, QS. al-Anfal/8: 73, dan QS. alAnfal/8:25.

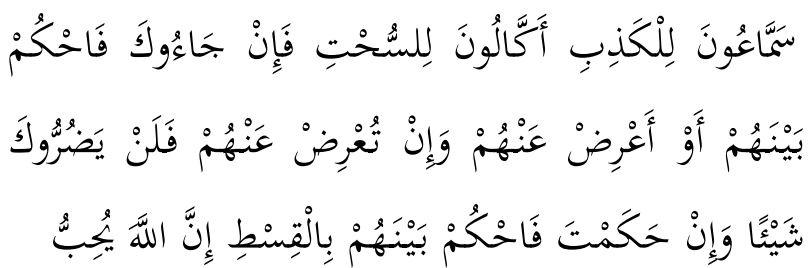

Artinya: "mereka itu adalah orang-orang yang suka mendengar berita bohong, banyak memakan yang haram. jika mereka (orang Yahudi) datang kepadamu (untuk meminta putusan), Maka putuskanlah (perkara itu) di antara mereka, atau berpalinglah dari mereka; jika kamu berpaling dari mereka, maka mereka tidak akan memberi mudharat kepadamu sedikitpun. dan jika kamu memutuskan perkara mereka, maka putuskanlah (perkara itu) di antara mereka dengan adil, Sesungguhnya Allah menyukai orang-orang yang adil".(Al-Maidah(5): 42).

Ayat tersebut di atas memberi penjelasan bahwa, setiap orang yang membuat keputusan atau kebijakan untuk suatu urusan atau permasalahan tertentu dia haruslah berlaku secara adil, sehingga dapat mewujudkan ketentraman bagi yang lainnya. Karena Allah menyukai orang-orang yang berlaku adil, sehingga tatkala Allah sudah meridhai seseorang yang berlaku adil, maka setiap orang yang ada di sekelilingnya juga akan merasa senang kepadanya, seperti halnya sabda Nabi dalam satu riwayatnya yang menyebutkan bahwa Allah senantiasa memberikan pertolongan kepada

\footnotetext{
${ }^{9}$ Adiwarman A. Karim, Ekonomi Mikro Islami, h. 35.
} 
hamba-Nya selama hamba tersebut memberikan pertolongan kepada sesamanya (wallahu fi 'aunil 'abdi mâda al-'abdu fi 'auni akhíhi).

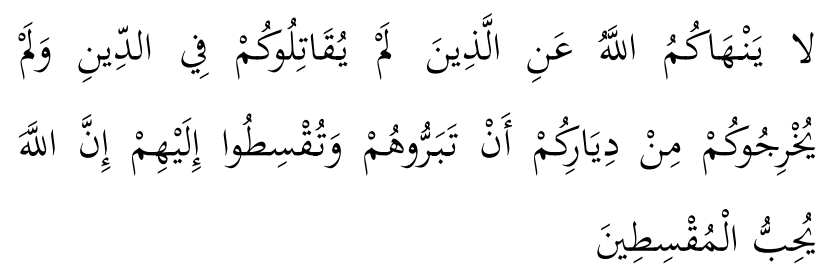

Artinya: "Allah tidak melarang kamu untuk berbuat baik dan berlaku adil terhadap orangorang yang tiada memerangimu karena agama dan tidak (pula) mengusir kamu dari negerimu. Sesungguhnya Allah menyukai orang-orang yang berlaku adil." (QS. al-Mumtahanah (60):8).

Keadilan mempunyai banyak arti, di antaranya adalah pertama, kepada masing-masing diberi pembagian yang sama. Kedua, kepada masing-masing diberi sesuai dengan kebutuhan. Ketiga, kepada masing-masing diberikan sesuai dengan usahanya. Keempat, kepada masingmasing diberikan sesuai dengan kontribusi sosialnya, dan Kelima, kepada masing-masing diberikan sesuai dengan kelebihannya atau keahliannya. $^{10}$

Pembagian yang sama untuk setiap orang yang bekerja adalah benar, apabila setiap orang punya pekerjaan yang sama dan tanggung jawab yang sama serta memiliki kebutuhan hidup yang sama. Masing-masing orang diberi sesuai dengan kebutuhannya. Hal ini juga benar karena setiap orang bisa jadi memiliki kebutuhan yang berbeda-beda seperti seorang anak dengan usia 8 tahun sekolah di Madrasah Ibtidaiyah, dia akan diberi uang saku dan uang belanja untuk kebutuhan sekolahnya berbeda dengan anak yang usianya 12 tahun sekolah di Madrasah Tsnawiyah, dan berbeda pula dengan anak yang usianya 15 tahun sekolah di Madrasah Aliyah. $\mathrm{Hal}$ ini disebabkan setiap mereka memiliki kebutuhan yang berbeda-beda antara yang satu dengan yang lain.

\footnotetext{
${ }^{10}$ Faisal Badrun dkk., Etika Bisnis dalam Islam, (Jakarta: Prenada Media Group, 2007), h. 49.
}

Pengertian adil yang ketiga adalah masingmasing orang diberikan bagian sesuai dengan hasil usahanya. Definisi ini adalah benar, karena setiap orang bekerja pastilah punya posisi yang berbeda-beda dan tanggung jawab yang berbeda pula, seperti halnya seorang tukang parkir atau bagian keamanan akan diberikan upah atau bayaran tentunya tidak sama dengan seorang marketing atau manajer, seorang sopir akan diberikan gaji yang berbeda dengan bagian cutomer service. Semuanya ini disesuaikan dengan seberapa besar usaha yang dilakukan oleh masing-masing orang. Termasuk juga ketika seseorang yang melakukan penjualan atas barang dagangannya selama delapan jam sehari sudah pasti akan mendapatkan hasil yang berbeda dengan orang yang melakukan kegiatan penjualan selama dua belas jam sehari, karena setiap orang akan mendapatkan sesuai dengan hasil usahanya. Adil dalam pengertian keempat adalah masing-masing orang diberikan sesuai dengan kontribusi sosialnya, yakni setiap individu akan mendapatkan penghargaan berupa materi atau non-materi dari orang sekelilingnya yang disesuaikan dengan kiprahnya dalam hubungan sosial dengan yang lain, seperti seorang tokoh masyarakat akan mendapatkan penghargaan yang lebih dari warga sekitarnya dibandingkan orang biasa yang bukan tokoh masyarakat, begitu juga dengan orang yang akhlaknya baik tentunya akan mendapatkan tempat yang pula di hati masyarakat dibandingkan dengan orang yang akhlaknya kurang baik.

Sedangkan adil dalam pengertian yang kelima adalah masing-masing orang akan diberi sesuai dengan kelebihan atau keahliannya, artinya spesifikasi setiap orang pastinya berbeda antara yang satu dengan yang lain, karena memang setiap manusia ini diciptakan oleh Allah dengan keunikannya masing-masing. Misalnya sebagian orang mempunyai kelebihan untuk mengelola zakat, sebagian yang lain mempunyai kemampuan untuk instalasi listrik, yang lain berkeahlian membuat bangunan. Masing-masing 
mereka sudah barang tentu akan mendapatkan bagiannya dalam mencari nafkah untuk kebutuhan hidupnya berbeda sesuai dengan kelebihan dan keahlian yang dimilikinya.

Beberapa definisi tentang keadilan di atas adalah benar, karena dalam Islam perbedaan dalam pendapatan itu dibolehkan, sebab dasar keadilan bagi semua adalah adanya kebebasan dalam melakukan pekerjaan dan ia akan mendapatkan income sesuai dengan pekerjaannya $^{11}$. Meskipun demikian, bukan berarti Islam menghendaki adanya perbedaan yang mencolok antara orang yang ekonominya menengah ke atas dengan orang yang ekonominya menengah ke bawah. Perbedaan yang sangat mencolok dalam hal gaya hidup memungkinkan timbulnya kesenjangan, sehingga hal ini haruslah dikurangi dan sumber-sumber ekonomi haruslah didistribusikan secara lebih merata, dengan tujuan agar kesenjangan tersebut tidak mengakibatkan rusaknya nilai-nilai persaudaraan yang bisa mengancam kehidupan bermasyarakat secara keseluruhan ${ }^{12}$.

\section{Kejujuran}

Dalam kamus besar bahasa Indonesia jujur diartikan sebagai lurus hati dan tidak curang. Sehingga kejujuran berarti ketulusan hati dan kelurusan hati ${ }^{13}$. Artinya, orang yang mempunyai sifat jujur dia senantiasa menjaga lisan dan perilakunya untuk selalu selaras dan konsisten. Dalam jiwa orang yang jujur terdapat nilai rohani yang menentukan sikap berpihak pada kebenaran, moral yang terpuji dan bertanggung jawab dalam melaksanakan tugas dan pekerjaannya sehingga ia hadir sebagai orang

\footnotetext{
${ }^{11}$ Faisal Badrun dkk., Etika Bisnis dalam Islam, h. 52.

${ }^{12}$ Faisal Badrun dkk., Etika Bisnis dalam Islam, h. 34.

${ }^{13}$ Kamus Besar Bahasa Indonesia, (Jakarta: Pusat Bahasa, 2008), h. $644 \& 645$
}

yang berintegritas dan mempunyai kepribadian yang terpuji dan utuh $^{14}$.

Dalam bahasa Arab jujur ini diistilahkan dengan amanah, yang sebenarnya mempunyai arti dapat dipercaya. ${ }^{15}$ Seperti halnya Rasulullah Saw. merupakan orang yang sangat amanah sejak masa mudanya sebelum diangkat oleh Allah menjadi Nabi dan utusan-Nya, dalam kisahnya seringkali Muhammad yang masih muda ini menjadi tempat bagi orang-orang yang mengenalnya dijadikan tempat untuk menitipkan barang-barang mereka, termasuk juga barang-barang berharga mereka, karena betapa masyhurnya kejujuran Muhammad ini di lingkungannya, meskipun ketika diangkat oleh Allah untuk menyampaikan risalah-Nya, maka tidak serta merta orang-orang yang mengenalnya sebagi orang jujur itu mempercayainya. Allah dalam firman-Nya menyinggung tentang perilaku jujur ini, yaitu :

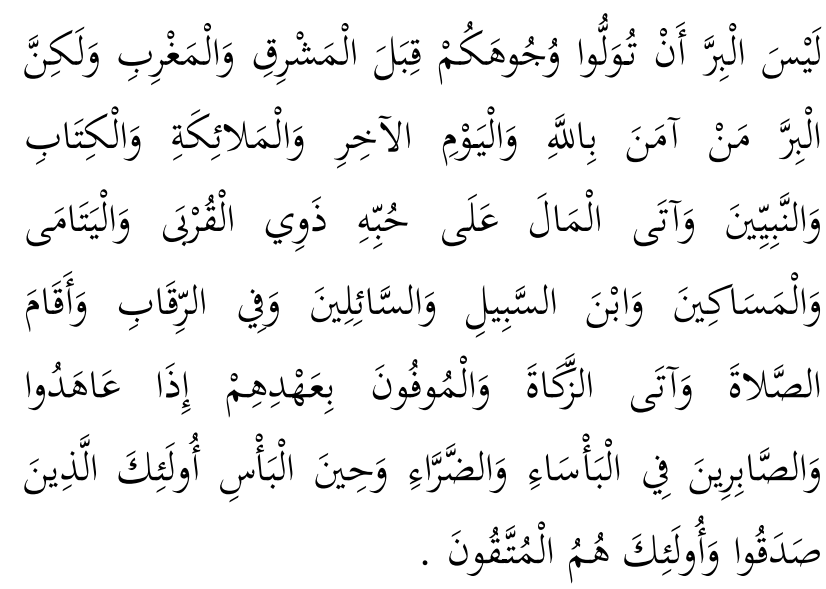

Artinya : "bukanlah menghadapkan wajahmu ke arah timur dan barat itu suatu kebajikan, akan tetapi sesungguhnya kebajikan itu ialah beriman kepada Allah, hari Kemudian, malaikat-malaikat, kitab-kitab, nabi-nabi dan memberikan harta yang dicintainya kepada kerabatnya, anak-anak yatim, orang-orang miskin, musafir (yang

\footnotetext{
14 Ma'ruf Abdullah, Manajemen Berbasis Syari'ah, (Yogyakarta: Aswaja Pressindo, 2012), h. 115.

15 A.W. Munawwir, Kamus Arab-Indonesia Al-Munawir, (Surabaya: Pustaka Progresif, 1997), h. 41.
} 
memerlukan pertolongan) dan orang-orang yang meminta-minta; dan (memerdekakan) hamba sahaya, mendirikan shalat, dan menunaikan zakat; dan orang-orang yang menepati janjinya apabila ia berjanji, dan orang-orang yang sabar dalam kesempitan, penderitaan dan dalam peperangan mereka. Itulah orang-orang yang benar (imannya); dan mereka itulah orang-orang yang bertakwa."(QS. al-Baqarah / 2 : 177).

Setiap muslim yang berlaku amanah selalu memperhatikan ucapannya ketika dia berucap, sehingga anggota badannya tidak akan digerakkannya kecuali setelah dia memikirkannya akan segala hal yang nantinya akan ditimbulkan dari ucapannya, misalnya ketika mengucapkan janji, maka dia akan selalu menepatinya, sebagaimana dalam ayat tersebut.

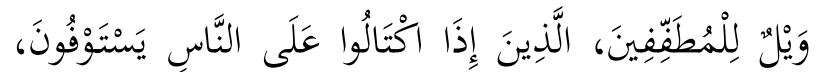

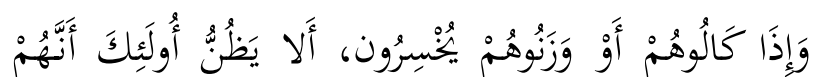

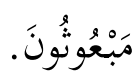

Artinya : "Kecelakaan besarlah bagi orang-orang yang curang. (yaitu) orang-orang yang apabila menerima takaran dari orang lain mereka minta dipenuhi, dan apabila mereka menakar atau menimbang untuk orang lain, mereka mengurangi. Tidaklah orang-orang itu menyangka, bahwa sesungguhnya mereka akan dibangkitkan”. (QS. al-Muthatifin/ 083 : 1-4).

Ayat di atas memberikan penjelasan bahwa tidaklah memberikan keuntungan praktikpraktik kecurangan dalam hal menimbang dan menakar sesuatu, yang mana hal ini seringkali dilakukan oleh orang-orang yang ketika mereka meminta untuk ditimbangkan, maka dia selalu mengharapkan keadilan bahkan kelebihan dari timbangan tersebut, tetapi ketika mereka melakukan pengukuran atau penakaran maka mereka menguranginya artinya tidak berlaku jujur untuk diri sendiri maupun orang lain. Perilaku ini menurut ayat di atas tidak akan dilakukan oleh seseorang ketika dia menyadari bahwa suatu ketika nanti dia akan dibangkitkan dari kematiannya dan melihat setiap perilaku buruknya akan diberi balasan oleh Allah sesuai dengan perbuatannya ketika hidup.

\section{Tidak Boleh Riba}

Istilah riba secara formal merupakan sebuah keuntungan tanpa nilai timbangan yang ditetapkan untuk salah satu dari dua pihak yang mengadakan kontrak tentang uang. Riba sebenarnya tidak terbatas pada bunga dari suatu tambahan pada pinjaman atau tabungan, akan tetapi juga suatu tambahan atas jual-beli barang. Riba ini dilarang dikarenakan secara logika merampas hak milik orang lain tanpa imbangan atau bahkan menyebabkan salah satu pihak terpaksa bekerja keras sementara pihak lainnya mendapat imbalan dengan cara yang mudah. ${ }^{16}$ Larangan riba ini berdasarkan banyak ayat-ayat Al-Qur'an yang menyinggungnya, di antaranya adalah :

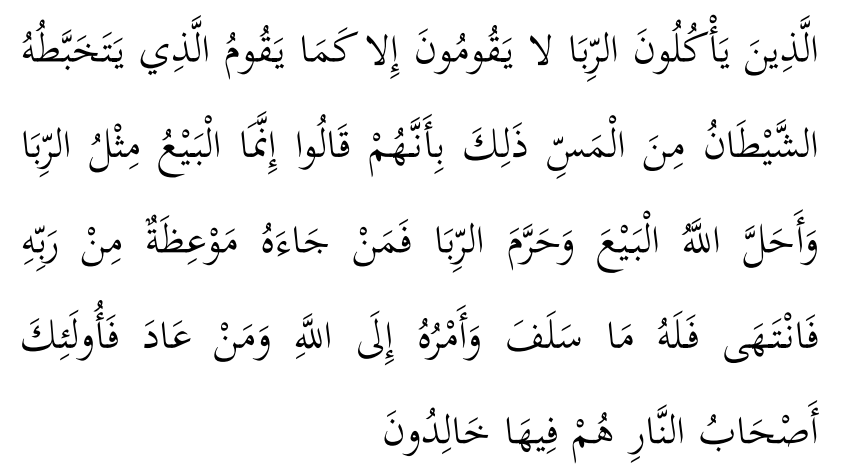

Artinya: “orang-orang yang makan (mengambil) riba tidak dapat berdiri melainkan seperti berdirinya orang yang kemasukan syaitan lantaran (tekanan) penyakit gila. Keadaan mereka yang demikian itu, adalah disebabkan mereka berkata (berpendapat), sesungguhnya jual beli itu sama dengan tiba, padahal Allah telah menghalalkan jual beli dan mengharamkan riba. Orang-orang yang telah sampai kepadanya larangan dari Tuhannya, lalu terus berhenti (dari mengambil riba), maka baginya apa yang telah

\footnotetext{
${ }^{16}$ Eti Roehaety dan Ratih Tresnawati, Kamus Istilah Ekonomi, (Jakarta: PT. Bumi Aksara, 2007), h. 290.
} 
diambilnya dahulu (sebelum datang larangan); dan urusannya (terserah) kepada Allah. Orang yang kembali (mengambil riba), maka orang itu adalah penghuni-penghuni neraka; mereka kekal di dalamnya”. (QS. al-Baqarah/ 2: 275).

Dari ayat tersebut terlihat sangat jelas, bahwasanya Allah sangat tidak meridhai perilaku riba yang senantiasa membawa kerugian bagi banyak pihak dalam jangka waktu dekat maupun dalam waktu jangka panjang, dengan firmanNya yang artinya berbunyi 'Allah menghalalkan jual beli dan mengharamkan riba'. Riba dimaksudkan di sini termasuk di dalamnya adalah menjadikan uang sebagai komoditi utama dalam hal sewa-menyewa dan jual beli, sehingga ada istilah jual-beli uang atau sewa menyewa uang, melalui praktik-praktik simpan pinjam dengan bunga yang sangat tinggi dan berlipat ganda, meskipun dengan dalih setiap saat nilai mata uang selalu mengalami penyusutan karena terjadinya inflasi atau kenaikan harga barangbarang yang tidak bisa diprediksi pergerakannya. Ayat lainnya yang serupa adalah:

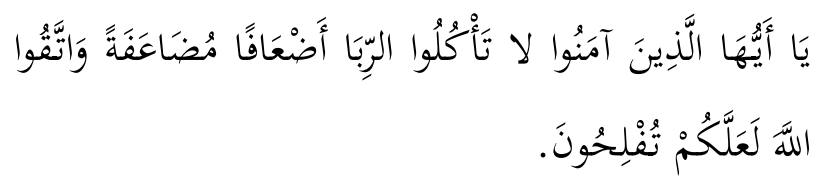

Artinya: "Hai orang-orang yang beriman, janganlah kamu memakan Riba dengan berlipat ganda dan bertakwalah kamu kepada Allah supaya kamu mendapat keberuntungan". (Ali Imran/3: 130)

Dalam ayat tersebut tujuan dilarangnya riba oleh Allah adalah untuk memberikan keuntungan yang hakiki bagi keberlangsungan hidup manusia, artinya praktik riba yang dilakukan oleh setiap orang, meskipun secara lahirnya menguntungkan karena memberikan imbalan yang berlipat lipat, namun pada hakikatnya adalah menghancurkan bagi pelakunya.

\section{Penutup}

Dengan demikian, materi-materi yang berhubungan dengan pendidikan ekonomi sangat penting untuk diterapkan, untuk memberikan pendidikan karakter anak-anak di tingkat dasar agar kelak mereka menjadi pribadi yang handal sesuai dengan syariat Islam. Pembelajaran yang tepat untuk anak-anak di sekolah dasar adalah yang bersifat pembentukan karakter (caracter building) untuk mempersiapkan masa depannya menjadi pribadi yang unggul. Oleh karena, itu materi-materi yang tepat sehubungan dengan pendidikan Ekonomi Islam pada jenjang Pendidikan Dasar adalah terkait kehidupan yang sejahtera, perilaku adil, kejujuran atau amanah, dan menghindari riba.

\section{Daftar Pustaka}

Abdullah, Ma'ruf, Manajemen Berbasis Syari'ah, Yogyakarta: Aswaja Pressindo, 2013.

Al-Asal, Ahmad Muhammad dan Fathi Ahmad Abdul Karim, Sistem, Prinsip, dan Tujuan Ekonomi Islam, terj: Imam Saefudin, Bandung: CV. Pustaka Setia, 1999.

Anto, Hendrie, Pengantar Ekonomika Mikro Islami, Yogyakarta: Ekonesia, 2003.

Badrun, Faisal dkk, Etika Bisnis dalam Islam, Jakarta: Prenada Media Group, 2007.

Roehaety, Eti, \& Tresnawati, Ratih, Kamus Istilah Ekonomi, Jakarta: PT. Bumi Aksara, 2007.

Hamalik Oemar, Proses Belajar Mengajat, Jakarta: PT. Bumi Aksara, 2012.

Hakim, Nurman, "Visi, Misi dan Nilai Perusahaan dalam pemasaran perbankan Syari'ah", dalam Jurnal Review of Islamic Economics, Finance, and Banking 1(1), 2013, Jakarta Pusat: Ikatan Ahli Ekonomi Islam. 
214 | TARBIYA | Vol. I, No.2, Desember 2014

Kamus Besar Bahasa Indonesia, Jakarta: Pusat Bahasa, 2008.

Karim, Adiwarman A. Ekonomi Mikro Islami, Jakarta: PT. Raja Grafindo Persada, 2008.
Munawwir, Ahmad Warson, Al-Munawwir: Kamus Arab-Indonesia terlengkap, Surabaya: Pustaka Progresif, 1997. 